\title{
Implementation of a Drug Allergy Testing Service in the Dermatology Outpatient Clinic of a Public University Hospital
}

\author{
Eudiana Vale Francelino ${ }^{1 *}$, Djanilson Barbosa dos Santos ${ }^{2}$, Luciana Mabel Félix Vasconcelos ${ }^{3}$, Elana Figueiredo Chaves ${ }^{1}$, Angelina Almeida \\ Bastos ${ }^{1}$, Janaira Fernandes Severo Ferreira ${ }^{4}$, Thereza Lúcia Almeida Prata ${ }^{5}$, José Wilson Accioly Filho ${ }^{5}$, Aparecida Tiemi Nagao-Dias ${ }^{3}$ \\ 'Department of Pharmacy, Federal University of Ceara, Fortaleza, Ceara, BRAZIL. \\ ${ }^{2}$ Núcleo de Epidemiologia e Saúde, Federal University of Bahia Reconcavo, Bahia, Salvador, BRAZIL. \\ ${ }^{3}$ Department of Clinical and Toxicological Analysis, Federal University of Ceará, Fortaleza, Ceará, BRAZIL. \\ ${ }^{4}$ Hospital Infantil Albert Sabin, Fortaleza, Ceara, Brazil R. Tertuliano Sales, 544 - Vila Uniao, Fortaleza - CE, BRAZIL.

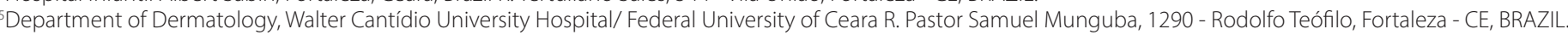

\begin{abstract}
Background: Investigation based solely on clinical history background is not sufficient to prove drug allergy and may lead to search for more expensive and potentially less effective alternative drugs. There are too few health centers that perform such tests in Brazil. Objectives: The aim of the present work was to structure and to systematize a service for in vivo drug skin testing in a public university hospital. Methods: The project was structured as follows: a) Divulgation about the service among health professionals and also among patients; b) Active search for suspicious cases; d) Referral to the allergist consultation; c) Performance of skin prick, intradermal and/or epicutaneous tests when requested. Results: Disclosure about the service was done through informal talk, workshop, flyers, advertisement. Active search for suspicious cases was done at the Dermatology Outpatient Clinics, Walter Cantídio Hospital School, Brazil. Ninety patients were evaluated by the allergist, and from these, 68 were submitted to drug skin tests. Thirty-five patients out of 68 presented clinical manifestations up to $2 \mathrm{~h}$ after drug intake and 33 , more than $2 \mathrm{~h}$ after drug intake. The drugs most implicated were NSAIDS and $\beta$-lactam drugs. Seventy-seven tests carried out. For immediate reading, 41 puncture tests and 12 intradermal
\end{abstract}

tests were performed. For delayed reading, 24 epicutaneous tests were done. Two patients presented positive prick test to dipyrone. Conclusion: For implementing an adequate and effective service for drug skin testing, technical and practical training of health professionals about drug safety is necessary, besides interdisciplinary collaboration and an adequate support by the hospital managers.

Key words: Patient Care, Skin drug test, Drug hypersensitivity, Drug allergy tests, Public hospital.

Correspondence

Ms. Eudiana Vale Francelino

Pharmacy Department, Federal University of Ceara, Fortaleza, Ceara, BRAZIL. Rua Capitao Francisco Pedro 1210, Rodolfo Teofilo, CEP: 60.430-370, Fortaleza, Ceara, BRAZIL.

Phone: +55 8533668293

Email: eudiana_vale@yahoo.com.br

DOI: 10.5530/jyp.2020.12.19

\section{INTRODUCTION}

Most adverse drug reactions are type A reactions, dose-dependent, predictable, including overdoses and pharmacological reactions. The type $\mathrm{B}$ reactions, on the other hand, comprise $10 \%$ of the adverse drug reactions, include drug intolerance, idiosyncratic reactions, hypersensitivity, are unpredictable, independent of dose. ${ }^{1}$ According to the World Health Organization, post-marketing drug surveillance should be performed taking into consideration the features of each group (e.g., children, newborns, pregnant women, elderly population, patients with chronic diseases). ${ }^{2}$ Drug allergy represents $15 \%$ of adverse drug reactions (ADRs), being antibiotics and Nonsteroidal Anti-Inflammatory Drugs (NSAIDs) most commonly implicated in the reactions. ${ }^{3}$ Therefore, it is important that health professionals may know how to adequately investigate the causal relationship between drug and an adverse reaction. On this aspect, a detailed clinical history is essential. Moreover, laboratory evaluation is necessary and depends on the suspected immunopathological mechanisms. For confirming drug allergy, cutaneous and epicutaneous tests are imprescindible tools. ${ }^{4}$ The positive predictive values of skin tests are considered to be very good for penicillin, muscle relaxants, heterologous sera and enzymes; suitable for vaccines, hormones and opiates; and poor or unknown for local anesthetics, sulfonamides, iodinated contrast media, NSAIDs and cephalosporins. ${ }^{5}$ Clinical history should contain the following aspects: ${ }^{3}$ a) Consistency of the patient's clinical history; b) Clinical manifestations; b) Timeline of the drug reaction c) Previous contact with the drug d) Personal and familiar background history of adverse drug reactions. When clinical manifestations, such as pruritus, angioedema and/or urticaria, occur till one hour or some hours after the last use of the drug, immune mechanisms derived from immediate hypersensitivity are probably responsible for the reactions. In these situations, prick and intradermal (immediate reading) tests are recommended. Provocation tests are the gold standard and should be employed after negative intradermal testing. They reproduce the drug reaction, regardless of the underlying immune or non-immune mechanisms involved. ${ }^{6}$ Epicutaneous tests are employed when delayed hypersensitivity is suspected. The pharmaceutical form used may be in tablet or liquid form and should be diluted in a suitable carrier such as petrolatum (5 to $30 \%) .^{7}$ Immune mechanisms in delayed hypersensitivity may cause clinical manifestations such as maculopapular exanthems, fixed drug eruption, contact allergic dermatitis, Steven Johnson syndrome or acute generalized exanthemous pustulosis. A limiting factor concerning skin tests is the lack of information about nonirritating drug concentrations and vehicles. ${ }^{6}$ The provocation test can be used for delayed hypersensitivity only in circumstances in which it is not potentially harmful for the patient, e.g. maculopapular exanthema. ${ }^{8}$ Based on the information mentioned above, investigation based solely on clinical history background is 
not sufficient to prove drug allergy and may lead to search for more expensive and potentially less effective alternative drugs. ${ }^{9}$ For implementing an adequate and effective service for drug skin testing, technical and practical training of health professionals about drug safety is necessary, besides interdisciplinary collaboration and information exchange among health centers. ${ }^{2}$ Confidence among team members is required, mainly due to the multidisciplinary responsibilities, and implicates in both individual and collective responsibility. ${ }^{10}$ The central idea of the present work was born some years ago because of a research project entitled Clinical and laboratory investigation of patients with suspicious drug allergy in a tertiary hospital. ${ }^{11}$ The authors had conducted an active search for suspicious cases of drug allergy among patients attending the Dermatology Outpatient Clinics at Hospital Universitario Walter Cantídio/Universidade Federal do Ceará, Brazil. Fifty-five patients with a supposed history of drug allergy were selected. At that time, skin tests were not available. An allergist, who voluntarily agreed to participate in the study, performed the tests. The dermatologist and the postgraduate Pharmacy students were trained to also be able to perform the tests. After the research project was concluded the team realized that skin test service should be implemented in the clinical routine. The interdisciplinary collaboration resulted in new knowledge to the area. ${ }^{12-14}$ Finally, the goal of the present work was to describe the establishment of a service for drug testing in a public hospital school.

\section{MATERIALS AND METHODS}

\section{Study design}

A descriptive study about an implementation of a drug allergy testing service was conducted in the period between 2014 and 2018 at the Dermatology Outpatient Clinic, Hospital Walter Cantidio/Universidade Federal do Ceara (HUWC/UFC). The project was approved by the HUWC Research Ethics Committee (376.779/13).

\section{Patients}

Inclusion criteria: Patients older than 4 years of age with suspected adverse cutaneous reactions assisted at the Dermatology Outpatient Clinic (HUWC/UFC).

Exclusion criteria: Pregnant women, patients with no possibility of drug suspension, for instance, those under use of corticosteroid or immunosuppressive therapy, or those under use of angiotensin-converting enzyme inhibitors and beta-blockers.

\section{Implementation of the service}

Task force group: For the implementation of the service, a multi-professional group was constituted and comprised medical residents, pharmacy students, postgraduate pharmacists, an allergist, a dermatologist, and a docent of Immunology. In order to facilitate communication among the team members, a virtual group was created; also, monthly meetings were organized in order to discuss about the various aspects of the project.

Disclosure about the implementation of the service: The following steps were done: a) An informal talk was presented every month to the new incoming fifth-year medical students and once a year to the dermatology residents; b) The patients were informed about the service through oral explanation and flyers; c) A one-day workshop was organized to disseminate knowledge about the service. Target audience included physicians, residents, pharmacists, pharmacy and medical students. Medical, biomedical and pharmaceutical professionals, including service staff, were invited to give lectures on diagnosis and immune mechanisms in drug allergy and, also lectures about process, structure and service organization.
Attributions of the pharmacist: The responsibilities of the pharmacist were implementation of the service for drug allergy test, training of the pharmacy students, drug handling, elaboration of the standard operating protocols, scheduling of the consultation appointment with the allergist, and performance of epicutaneous testing.

Attributions of the pharmacy students: The pharmacy students were trained to actively search for suspicious cases in the waiting room twice per week before the dermatology consultation. They were also responsible for explaining the project to the patients and, after informed consent, they should apply a questionnaire adapted from Demoly et al. ${ }^{3} \mathrm{~Pa}$ tients aged 8 to 17 years old should also agree with the project and sign a proper form. The pharmaceutical questionnaire contained information concerning the following aspects: a) socio-demographic profile of the patient; b) drugs prescribed and over-the-counter medications; c) timeline of the drug exposure to the event; d) description of the reaction, e) background clinical history (Figure 1).

Attributions of the dermatologist and allergist: The dermatologist was responsible for evaluating every patient with suspicious reactions and for informing the pharmacist, when an adverse drug reaction may have occurred. Next, an appointment with the allergist should be scheduled. The allergist who collaborated voluntarily with the project, should proceed with the investigation in order to confirm or to refute the hypothesis of drug allergy. Skin testing would be scheduled upon request. The allergist was responsible for performing cutaneous tests and for interpreting the cutaneous and epicutaneous tests.

Skin drug allergy service: The flowchart of the patient referral to the allergy testing service was scheduled as shown in Figure 2. The various aspects of the service are described below.

Appropriate room for the service - The skin tests were performed in an equipped emergency room.

Appointment - Appointment scheduling of skin testing was conducted (by telephone), taking into account a minimum period of at least six weeks after the last contact with the drug. The patient was told to stop using corticosteroids (up to three weeks before testing) and antihistamines (at least 5 - 7 days before testing). ${ }^{6}$ Three days before the test, the patient would receive a phone call to confirm his or her attendance.

Protocols for drug handling - Standard operating protocols for drug handling were established according to described elsewhere. ${ }^{7,15}$ Good practices for drug handling are regulated by the Collegiate Board Resolution and the National Health Surveillance Agency (ANVISA). ${ }^{16}$ The Federal Council of Medicine in Brazil, in accordance with resolution 1794/06, ${ }^{17}$ establishes rules for the use of allergen extracts for diagnostic and therapeutic purposes.

Skin test performance and result interpretation - The skin tests were performed according to the literature. ${ }^{7,15,18-20}$ The puncture (1 drop on the forearm surface) and intradermal skin tests (volumes $0.03 \mathrm{~mL}-0.05 \mathrm{~mL}$ applied with the aid of a syringe) were read after 20 minutes. Histamine was the positive control and $0.9 \%$ saline, the negative control. Intradermal tests were done upon negative result of the prick test. In the case of the epicutaneous test, drugs were dissolved to achieve $10 \%$ in petrolatum. Afterwards, they were applied to the patients's using Finn Chambers chambers mounted on adhesive tapes (Scanpor'). Reading was done after $48 \mathrm{~h}, 72 \mathrm{hr}$ and $96 \mathrm{hr}$.

Upon positive result - The patient with a positive result would be informed and would receive a card identification and also a folder informing about other drug alternatives. An ADR notification form ${ }^{21}$ would be filled by the physician or the pharmacist and sent to the Centro de Farmacovigilância do Ceará (CEFACE). After, it would be forwarded through the on-line system to the Agência Nacional de Vigilância da Saúde (ANVISA). 
Customer satisfaction: Survey questions were applied in order to evaluate the quality of the service, using a 5-category Likert scale ${ }^{22}$ to analyze the responses.

\section{RESULTS}

One hundred forty-five patients joined the project, but only 90 patients were evaluated by the allergist. The others were excluded from the study by some reasons, such as not being present after three attempts for scheduling the appointment. From those evaluated by the specialist, 68 patients (75.5\%) presented suspected drug allergy. Twenty-two patients (24.5\%) were excluded by the allergist based on the following aspects: a) The patient was allergic to multiple NSAIDs (in this case, alternative therapeutics were suggested); b) The patient could not interrupt the use of corticosteroid and/or antihypertensive drugs; c) The patient was reexposed to the drug without any evidence of hypersensitivity reaction; d) The patient presented confounding factors (e.g., viral infection or other co-morbidities); e) The chronology of the reaction did not correlate with the patient's clinical history.

Thirty-five patients presented clinical manifestations up to $2 \mathrm{~h}$ after drug intake (51.5\%) and 33, more than $2 \mathrm{~h}$ after drug intake (48.5\%). NSAIDS were the probable causing agents in 24 out of 35 patients $(68.6 \%)$ in immediate adverse reaction and in 7 out of 33 patients $(21.2 \%)$ in delayed adverse reaction. bhirty-five patients presented clinical manifestations up to $2 \mathrm{~h}$ after drug intake (51.5\%) and 33, more than $2 \mathrm{~h}$ after drug intake (48.5\%). NSAIDS were the probadverse reaction. Clinical manifestations mentioned by the patients who suffered of immediate reactions were air distress, redness, itching, flushing, swelling of lips, throat, eyes. Clinical manifestations mentioned by the patients who suffered of delayed reactions included redness, flushing, blisters, contact dermatitis.

Seventy-seven tests were carried out as follows: For immediate reading, 41 puncture tests and 12 intradermal tests were performed. Intradermal testing should be done only upon negative result of the puncture test. For delayed reading, 24 epicutaneous tests were done. In regard to the prick tests, two patients presented positivity for dipyrone what confirmed drug allergy. All the intradermal tests done resulted negative. In regard to the epicutaneous testing, all the results were negative (Table 1).

Customer satisfaction regarding the allergy testing service has also been assessed. Ninety patients were interviewed and as mentioned in Table 2, in general, they stated very positively about the service. More than 50\% of them were very satisfied with the service proposal, quality of care, place of service, among other points.

\section{DISCUSSION}

Drug allergy is an area that has achieved significant new scientific knowledge in the last 18 years, and several factors have been described that may contribute to its occurrence, for instance, age, sex, simultaneous use of several drugs, alcoholism, HLA haplotype, drug metabolism, among others. ${ }^{23}$ For confirming drug allergy, diagnostic tool is necessary; nonetheless, although there are several protocols that have not been validated, there is still a vast literature that makes one's task much easier for performing the tests and for selecting which drugs can be tested. ${ }^{1,5-9,15,18-20}$

Table 1: Suspicious drugs, clinical manifestations, time of the reaction, type of skin test, and results of the skin tests.

\begin{tabular}{|c|c|c|c|c|c|}
\hline Drug (s) & $\mathrm{N}(\%)$ & Clinical manifestations & $\begin{array}{l}\text { Time of the } \\
\text { reaction }\end{array}$ & Test applied & Results \\
\hline Paracetamol & $1(3,6 \%)$ & $\begin{array}{l}\text { Air distress / heat / dark } \\
\text { spots }\end{array}$ & $<2 \mathrm{hrs}$ & Prick test & Negative \\
\hline $\begin{array}{l}\text { Sulfamethoxazole }+ \\
\text { trimethoprim }\end{array}$ & $2(7,2 \%)$ & $\begin{array}{l}\text { Redness / flushing / dark } \\
\text { spots / blisters }\end{array}$ & $>2 \mathrm{hrs}$ & Epicutaneous test & Negative \\
\hline $\begin{array}{l}\text { Sulfamethoxazole }+ \\
\text { trimethoprim }\end{array}$ & $1(3,6 \%)$ & $\begin{array}{l}\text { Air distress/redness/ } \\
\text { swelling of the lips }\end{array}$ & $<2 \mathrm{hrs}$ & Prick test & Negative \\
\hline Dipyrone & $\begin{array}{l}7(25 \%) \\
4(14 \%)\end{array}$ & $\begin{array}{l}\text { Redness /breathlessness/ } \\
\text { swelling of the lips/ } \\
\text { tingling / throat swelling }\end{array}$ & $\begin{array}{l}<2 \mathrm{hrs} \\
<2 \mathrm{hrs}\end{array}$ & $\begin{array}{c}\text { Prick test } \\
\text { Prick test/Intradermal }\end{array}$ & $\begin{array}{c}\text { Positive (one) } \\
\text { Negative/ } \\
\text { Negative }\end{array}$ \\
\hline \multirow[t]{2}{*}{ Dipyrone } & $1(3,6 \%)$ & $\begin{array}{c}\text { Redness/ eyes swelling/ } \\
\text { flushing }\end{array}$ & $<2 \mathrm{hrs}$ & Prick test & Positive \\
\hline & & Redness/itching & & & \\
\hline Dipyrone & $1(3,6 \%)$ & \multirow{2}{*}{$\begin{array}{l}\text { dark spots/ blisters/ } \\
\text { redness }\end{array}$} & $>2 \mathrm{hrs}$ & Epicutaneous test & Negative \\
\hline Dipyrone & $2(7,2 \%)$ & & $>2 \mathrm{hrs}$ & Epicutaneous test & Negative \\
\hline Ketoprofen & $1(3,6 \%)$ & Eye swelling & $<2 \mathrm{hrs}$ & Prick test & Negative \\
\hline Diclofenac & $3(11 \%)$ & $\begin{array}{l}\text { Eye swelling/ redness/ } \\
\text { flushing }\end{array}$ & $<2 \mathrm{hrs}$ & Prick test & Negative \\
\hline Ibuprofen & $1(3,6 \%)$ & Redness / itching & $>2 \mathrm{hrs}$ & Epicutaneous test & Negative \\
\hline Acetylsalicylic acid & $4(14 \%)$ & $\begin{array}{l}\text { Eye swelling / redness } \\
\text { / swelling of the eyes } \\
\text { / itching/ flushing / } \\
\text { swelling of the throat / } \\
\text { tingling }\end{array}$ & $<2 \mathrm{hrs}$ & Prick test & Negative \\
\hline
\end{tabular}




\section{Socio demographic Questionnaire}

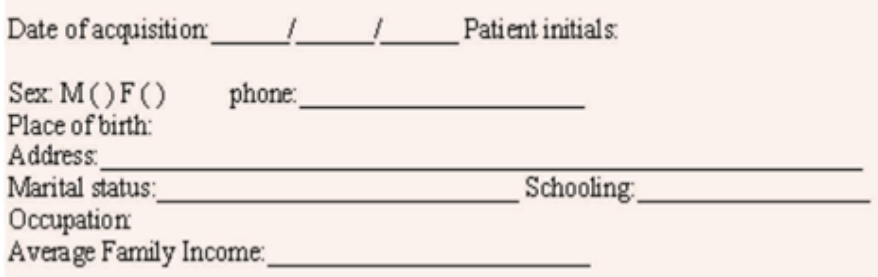

\section{Profile of Use of Medications and Adverse Events}

- Do you have any chronic disease? If so, which one(s)?

- If you are hypertensive, do you use ACE inhibitors or $\beta$ blockers?

- Which drugs do you use for disease treatment?

- Do you make use of other drugs not prescribed by a doctor?

- Did you experience any drug side effects?

- If yes, report the type of reaction, the time interval between the exposure to the drug and the reaction

- Was drug use suspended?

- Have you experienced recurrence of the reaction?

- Do you have any allergies? To what?

- Do you have a family history ofallergies?

\section{Profile use of Oupatient Service}

- What is your means of transport for getting to the hospital?

- How long did it take you to reach the hospital?

- How long did you wait before your medical consultation?

- How long did you wait prior to receiving your skin test?

Figure 1: Patient data Sheet

Table 2: Customer satisfaction in respect to the allergy testing service.

\begin{tabular}{cc}
\hline Question & Level of satisfaction (\%) \\
\hline Service provided & Very satisfied (95) \\
Attention by health professionals & Very satisfied (97) \\
Location of service & Very satisfied (71) \\
Opening Hours & Very satisfied (68) \\
Cleaning and hygiene & Very satisfied (63) \\
Guidance provided & Satisfied (87) \\
Waiting time to perform the test & Satisfied (71) \\
\hline
\end{tabular}

A study conducted in 22 allergy units in 11 Latin American countries among them, Brazil, showed that $15 \%$ of the population had already presented at least one hypersensitivity reaction in life due to re-exposure to drugs to which they were sensitized. ${ }^{24.25}$ Too few health centers that perform drug skin tests are available in Brazil. ${ }^{26,27}$

In general, there is not a team of professionals but only the allergist, who is responsible for all steps of the process, that is, patient diagnosis, drug handling, skin test performance and interpretation, ADR notification.

On the contrary, multidisciplinary collaboration is the hallmark of our present work. In order that this type of project could be successful, we realized that it was imperative that the service should be implemented by a task force group comprised by health professionals from different areas, including pharmacists, dermatologists, allergists, basic immunologists, nurses, undergraduate students.

The service performed 77 tests in 68 patients with suspected drug allergy. In 2 patients it was possible to confirm drug allergy to dipyrone. In the circumstances that both the prick and intradermal tests were negative, it

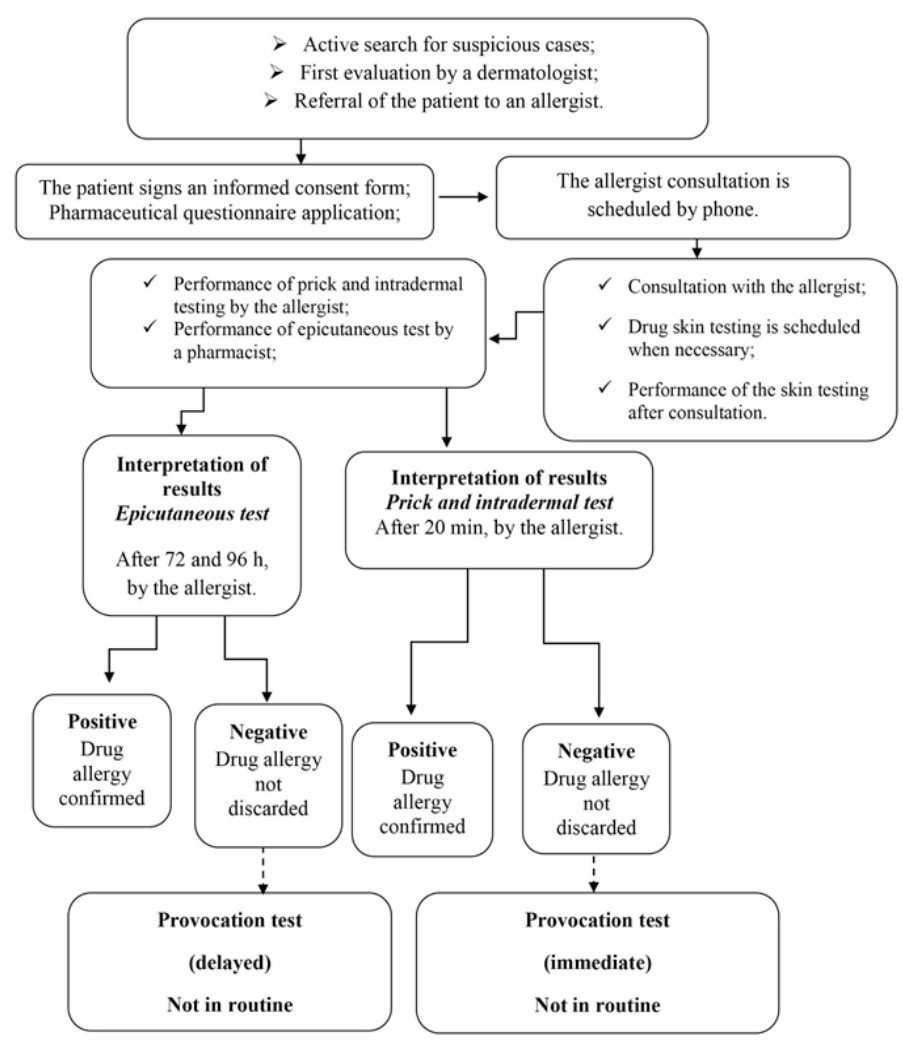

Figure 2: Flowchart of patient referral to the allergy testing service

was recommended that provocation tests could be performed. Unfortunately, they could not be performed due to lack of structure within the hospital, especially in regard to the unavailability of beds in intensive care units and also due to the lack of an allergist in the hospital staff. According to Chiriac and Demoly ${ }^{27}$ the provocation test is considered the gold standard reference for confirming drug allergy. It presents high sensitivity, but it is necessary to be performed in hospital environment, with proper emergency equipment and under the supervision of a medical staff in order to avoid serious events.

The questionnaire of satisfaction revealed that the patients believe that the service of drug allergy testing is necessary and relevant. According to Travassos et al. ${ }^{28}$ a specific service depends on individual and collective necessity. A service may be classified into four dimensions: political, economic, technical and symbolic. There are some variables that can be used for evaluating a service (e.g., access, accessibility, functional adequacy, financial ability and acceptability). Our service demonstrated a direct benefit to the patients, due to their low cost, good accessibility, safety, and usefulness for clinical approach.

It is important to remind that although the participants of the study were aware about the necessity of establishing a drug allergy testing service at a university hospital, it is a difficult task to convince hospital managers that is worthwhile that the service be available for the clinical routine and not only for academic research. In this regard, it is necessary that they be aware of the importance about investigating drug allergy. The implementation of the service faces another huge obstacle that is the lack of an allergist in the hospital staff.

In order to evaluate the situation of an allergy service in a community in Madrid, Dominguez-Ortega et al. ${ }^{29}$ highlighted the following positive aspects: Proximity between hospital centers and specialists and existing tradition of an academic and research practice of the professionals involved. Among the negative points, there was lack of knowledge among 
managers about the necessity of an allergist and an increase in the prevalence of allergic diseases without an adequacy of resources to treat them. In regard to our proposal, after our project had been concluded, it was not implemented in routine service of the Hospital Universitário Walter Cantídio because of the reasons discussed earlier. Nonetheless, we were invited to cooperate in the allergy outpatient service, Hospital Infantil Albert Sabin, HIAS, Fortaleza, Ceara, Brazil. The partnership was successful and the first results have been described elsewhere. ${ }^{30}$

\section{CONCLUSION}

The implementation of a service of drug skin test at a hospital school is facilitated when a multidisciplinary team is consisted of health professionals and academic students that work altogether. The patients themselves recognize the importance of such a service. There is a challenge, however, to convince hospital managers about the relevance of investigating drug allergy. There are several arguments that can be stated about the importance of such a service, as follows: a) Greater safety in prescribing; b) Reduction of hospital costs caused by unnecessary re-exposures and/or exchange for high-price drugs with lower effectiveness.

\section{ACKNOWLEDGEMENT}

We are thankful to the Pharmacy academics, Sarah Resende, Gabriela Abreu and Natália Frota and to medical residents and students for skillful collaboration.

\section{CONFLICT OF INTEREST}

The authors declare no conflict of interest

\section{ABBREVIATIONS}

ADRs: Adverse Drug Reactions; NSAIDS: Nonsteroidal Anti-Inflammatory Drugs; HUWC/UFC: Hospital Walter Cantidio/Universidade Federal do Ceara; ANVISA: National Health Surveillance Agency; CEFACE: Centro de Farmacovigilância do Ceará; HLA: Human leukocyte antigen; ACE: Angiotensin-converting enzyme; HIAS: Hospital Infantil Albert Sabin.

\section{REFERENCES}

1. Kowalski ML, Demoly P, Pichler WJ, Sanchez-Borges M. Hypersensitivity to drugs and biological agents. WAO White Book on Allergy, Milwaukee: WAO. 2012;57-61.

2. Donaldson L, Philip P. Patient safety: A global priority. B World Health Organ. 2004;82(12): 892.

3. Demoly P, Pichler W, Pirmohamed M, Romano A. Important questions in allergy: 1 - drug allergy/hypersensitivity. Allergy. 2008;63(5):616-9.

4. Samel AD, Chu CY. Drug Eruptions. [cited 2016 May 09] Available from: http:// www.uptodate.com/contents/drug-eruptions.

5. Gruchalla RS, Pirmohamed M. Clinical practice. Antibiotic allergy. New Engl J Med. 2006;354(6):601-9

6. Demoly P, Adkinson NF, Brockow K, Castells M, Chiriac AM, Greenberger PA, et al. International Consensus on drug allergy. Allergy. 2014;69(4):420-37.

7. Barbaud A, Gonçalo M, Bruynzeel D, Bircher A. European Society of Contact Dermatitis: Guidelines for performing skin tests with drugs in the investigation of cutaneous adverse drug reactions. Contact Dermatitis. 2001;45(6):321-8.

8. Gomes ER, Brockow K, Kuyucu S, Saretta F, Mori F, Blanca-Lopez N, et al. Drug hypersensitivity in children: report from the pediatric task force of the EAACl Drug Allergy Interest Group. Allergy. 2016;71(2):149-61. doi: 10.1111/all.12774.
9. American Academy of Allergy, Asthma and Immunology (AAAAl); The American College of Allergy, Asthma and Immunology; The Joint Council of Allergy, Asthma and Immunology. Drug allergy: An updated practice parameter. Allergy Asthma Cl Im. 2010;105(4):259-73.

10. Valentim IV, Kruel AJ. A importância da confiança interpessoal para a consolidação do Programa de Saúde da Família. Cienc Saúde Coletiva. 2007;12(3):77788

11. Vasconcelos LM. Investigação clínico-laboratorial de pacientes com suspeita de reações de hipersensibilidade alérgica a fármacos em hospital terciário. Fortaleza (CE): Universidade Federal Do Ceará. 2012;112

12. Teixeira FM, Vasconcelos LMF, Araujo TS, Vasconselos AMA, Almeida TLP, Nagao-Dias AT. Rifamycin-associated postoperative allergic contact dermatitis in a 70-year old patient. J Invest Allerg Clin. 2013;23:282-3

13. Teixeira FM, VasconceloS LM, Rola CDEA, DePrata ATL, Valença JTJR, Nagao-Dias AT. Secondary leprosy infection in a patient with psoriasis during treatment with infliximab. J Clin Rheumatol. 2011:17(5):269-71.

14. Teixeira FM, Vasconcelos LMF, Araujo TS, Vasconselos AM, Almeida TLP, Nagao-Dias AT. Association of CD69 and CD25 activation markers on CD4 and CD8 cells with skin tests in drug allergy. J Pharmacovigil. 2013;1:3-6.

15. Brockow K, Garvey LH, Aberer W, Atanaskovic-Markovic M, Barbaud A, Bilo $\mathrm{MB}$, et al. Enda/eaaci drug allergy interest group. Skin test concentrations fo systemically administered drugs - an enda/eaaci drug allergy interest group position paper. Allergy. 2013;68(6):702-12.

16. Agência Nacional De Vigilância Sanitária. Anvisa. Resolução RDC $n^{\circ} 214$ de 19 de dezembro de 2006. Dispõe sobre boas práticas de manipulação de medicamentos para uso humano em farmácias. 2006. [cited 2014 Mar 14] Available from: http://www.cff.org.br/userfiles/file/resolucao_sanitaria/214.pdf

17. Brasil. Conselho Federal de Medicina. Resolução $n^{\circ} 1.794$, de 11 de agosto de 2006. Estabelece as normas mínimas para a utilização de extratos alergênicos para fins diagnósticos e terapêuticos nas doenças alérgicas. 2006. [cited 2015 Sep 16]. Available from: http://www.portalmedico.org.br/resolucoes/ CFM/2006/1794_2006.htm

18. Malaman MF, Rodrigues AT, Felix MM, Menezes UP, Tanno LK, Nunes IC et al. Recomendações para o diagnóstico das reações de hipersensibilidade imediatas aos antibióticos beta-lactâmicos. Rev Bras Alerg Imunopatol. 2011:34(6):257-62

19. Tanno LK, Ensina LFC, Aun MV, Ribeiro MR, Rodrigues AT, Garro LS, et al. Drug patch tests in evaluation of non-immediate hypersensitivity reactions. Rev Bras Alerg Imunopatol. 2011;34(6):251-6.

20. Soyer O, Sahiner UM, Sekerel BE. Pro and contra: Provocation tests in drug hypersensitivity. Int J Mol Sci. 2017;18(7):1437.

21. Coêlho HL, Arrais PS, Gomes AP. Sistema de Farmacovigilância do Ceará: Um ano de experiência. Cad Saúde Pública. 1999;15(3):631-40.

22. Likert RA. Technique for the measurement of attitudes. Arch Psychol 1932:140:1-55.

23. Alomar MJ. Factors affecting the development of adverse drug reactions: Review article. Saudi Pharm J. 2014;22(2):83-94

24. Jares EJ, Baena-Cagnani CE, Sánchez-Borges M, Ensina LF, Arias-Cruz A, Gómez $\mathrm{M}$, et al. Drug induced anaphylaxis in Latin American countries. J Aller Cl Imm-Pract. 2015;3(5):780-8.

25. Ensina LF, Lacerda AE, DeAndrade DM, Machado L, Camelo-Nunes I, Solé D Drug-induced anaphylaxis in children: Nonsteroidal anti-inflammatory drugs and drug provocation test. J Aller Cl Imm-Pract. 2014;2(6):825.

26. Felix MMR, Queiroz GRS, Aranda CS, Aun MV, Menezes UP, Rodrigues AT, et al. Hipersensibilidade a anti-inflamatórios não esteroidais em crianças: Relato de dois casos e revisão das novas classificações. Braz J Allergy Immunol. 2017;1(4):410-6

27. Chiriac AM, Demoly P. Drug provocation tests: Up-date and novel approaches. Allergy Asthma Cl Im. 2013;9(1):12.

28. Travassos C, Viacava F, Fernandes C, Almeida CM. Desigualdades geográficas e sociais na utilização de serviços de saúde no Brasil. Cienc Saúde Coletiva. 2000;5(1):133-49.

29. Domínguez-Ortega J, Ruiz Hornillos J, Chivato T, DeHoz BL, Elices A, Iglesias A, et al. La alergología en el sistema sanitario público de la Comunidad de Madrid: situación actual y oportunidades en el sistema sanitario público del siglo XXI. An Sist Sanit Navar. 2014;37(3):317-27.

30. Francelino EV, Araújo SR, Ferreira JF, DeAraújo FM, Bulgarelli KB, Nunes PB, et al. Investigating True $\beta$-lactam Allergy in the Outpatient Allergy Clinics at a Public Children's Hospital, Ceará, Brazil. J Young Pharm. 2019;11(1):88-91.

Article History: Submission Date :23-08-2019; Revised Date : 01-12-2019 ; Acceptance Date : 27-12-2019

Cite this article: Francelino EV, Santos DB, Vasconcelos LMF, Chaves EF, Bastos AA, Ferreira JFS, Prata TLA, Filho JWA, Nagao-Dias AT. Implementation of a Drug Allergy Testing Service in the Dermatology Outpatient Clinic of a Public University Hospital. J Young Pharm. 2020;12(2):94-8. 